\title{
The Low of Kapuas Hulu Local Government Role for Registering Kerupuk Basah as Geographical Indication
}

\author{
Yenny AS ${ }^{1}$, Charlyna S. Purba ${ }^{2}$ \\ \{yenny.upb@gmail.com ${ }^{1}$, charlyna.purba@gmai.com ${ }^{2}$ \} \\ ${ }^{1,2}$ Faculty of Law, Universitas Panca Bhakti, 78113, Indonesia
}

\begin{abstract}
Putussibau is the capital of Kapuas Hulu Regency, located in the upstream of the Kapuas River as the longest river in Indonesia, with Toman and Belidak fish that could be processed into Kerupuk Basah. Kerupuk Basah has a high selling value and is famous in West Kalimantan Province as a particular food from Putussibau region. Unfortunately, Kerupuk Basah has not been registered in Directorate General of Intellectual Property as Geographical Indication. Based on Article 53 paragraph (3) point b of Law 20 of 2016 on Trademark and Geographical Indication, Kapuas Hulu Local Government may register KerupukBasah. Through empirical research method, the researchers will measure Kapuas Hulu Local Government's role in preserving Kerupuk Basah as Putussibau's typical food. The results of the study showed that the Kapuas Hulu Local Government has a low role in preserving Kerupuk Basah. The unregistered KerupukBasah evidenced this as a Geographical Indication. Such low attention shown by the Kapuas Hulu Local Government is influenced by the lack of understanding of Kapuas Hulu Local Government about the importance of developing KerupukBasah as Putussibau typical food and preserving it through the registration of Wet Crackers to the Directorate General of Intellectual Property Rights. The researchers suggest the Directorate General of Intellectual Property advocate Kapuas Hulu Local Government about the importance of Kerupuk Basah Putussibau registration as a geographical indication (Abstract)
\end{abstract}

Keyword: low, Local Government, role, geographical indication (keywords)

\section{Introduction}

Kapuas Hulu, which is known by "Bumi Uncak Kapuas," is the biggest fish producing area from headwaters (freshwater fish) in West Kalimantan. Consequently, no wonder if most of this area's typical foods are made from freshwater fishes in Kapuas River. One of them is Kerupuk Basah, which is called by the local community as "temet."

This unique Kerupuk Basah is made from freshwater fish, especially Belinda and toman fish that only can be found in the headwaters in Kapuas Hulu as Kapuas Hulu geographical condition consists of watercourses. Kerupuk Basah in Kapuas Hulu can be said as a symbol which needs to be protected by communal intellectual property.

Geographical indication protection of this processed food of Kerupuk Basah is expected to improve its product value in order to raise the economy of the people, especially the fisheries sector in Kapuas Hulu. Geographical indication concept is mutual protection. The implementation of geographical indication protection process can be done by empowering Government institution or non-Governmental institution and the local community to register the product as a geographical indication. 
However, communal geographical indication registration in order to protect Kerupuk Basah from Kapuas Hulu is not obtained until now. Thus, Kerupuk Basah value, increasing efforts to improve their social welfare level is not achieved.

Based on the research observation, Kerupuk Basah not being protected as Kapuas Hulu geographical indication is influenced by the low commitment of role occupant. There is also a lack of acknowledgment from the governmental actors on protecting place-based products as a geographical indication that ought to be as intellectual property rights [1]. Administration coordination and perception equation are urgently required for common geographical indication in order to improve economic value for society welfare [2][3].

Therefore, this study is conducted to reveal obstacles in increasing the role of stakeholders and significant efforts to be done in order to realize the protection of Kepuruk Basah as Kapuas Hulu's common geographical indication.

\section{Methodology}

The study used a socio-legal research method to give the analysis of the low Kapuas Hulu Local Government role in registering Kerupuk Basah as Kapuas Hulu common geographical indication.

\section{Findings}

\subsection{Kapuas Hulu Overview}

Geographically, Kapuas Hulu is located in $0,5^{0}$ North Latitude until $1,4^{0}$ South Latitude and $111,40^{\circ}$ until $114,10^{\circ}$ East Longitude, with Putussibau as the capital city. In the North bordering with Sarawak (East Malaysia), West and South bordering with Sintang and Malawi, while in the East bordering with East Kalimantan and Central Kalimantan.

Kapuas Hulu extends from the West to the East, approximately $240 \mathrm{~km}$ distance and widen from the North to the South with approximately $126,70 \mathrm{~km}$. Kapuas Hulu is located at the eastern of West Kalimantan, with approximately $657 \mathrm{~km}$ distances by road, and 842 $\mathrm{km}$ by Kapuas River. Travel time to Pontianak is approximately one hour and forty-five minutes by flight type ATR 42 Seri 300/F27 aircraft series or approximately 16 hours by vehicle.

Overall, Kapuas Hulu is an eroded area and it gets older from time to time, which is characterized by small and winding river gradient. Generally, Kapuas Hulu area morphology is in the form of a skillet (cauldron) consisting of lowland/sunken concave that extends water from downstream Nanga Manday that continues to the West following Kapuas River, flowing to Nanga Suhaid.

Semitau, as part of Kapuas Hulu, consists of lakes and swamps with deep water. While the lowland, which is not a lake submerged in water twice a year for $1 / 2$ until six months. In this lowland, there is the capital of the subdistrict which population is relatively crowded. This lowland is at an altitude of approximately 31-46 meters above sea level.

The plateau/tilt interspersed by longitudinal swamps but narrow or punctuated by small hills. This plain belongs to a category that is usually flooded at certain times, i.e., when there is a high rainfall that causes water flooding for $2-5$ hours only. This high/sloping plateau lies at an altitude of about 4,761 meters above sea level.

Kapuas Hulu is the second largest area (after Ketapang) in West Kalimantan. The total area of Kapuas Hulu is $29.842 \mathrm{~km}^{2}$, equal to $20,33 \%$ of the whole West Kalimantan total 
area $146.807 \mathrm{~km}^{2}$. From 23 sub-district in late 2012, there are three largest sub-district, i.e., North Putussibau, South Putussibau and Embaloh Hulu with each coverage of 4.521,86 $\mathrm{km}^{2}, 6.352,33 \mathrm{~km}^{2}$, and $3.560,00 \mathrm{~km}^{2}$, or equivalent to $14.51 \%, 20.38 \%$, and $11.42 \%$ of Kapuas Hulu area. Whereas, both Pengkadan sub-district and PuringKencana are the smallest areas where each sub-district only covers less than $500 \mathrm{~km}^{2}$ or less than $1.5 \%$ of the whole area. Administratively, Kapuas Hulu boundaries are as follows:

a. In the North is bordering with Sarawak (East Malaysia)

b. In the East is bordering with Central Kalimantan and East Kalimantan

c. In the West is bordering with Sintang

d. In the South is bordering with Sintang and Central Kalimantan

From Kapuas Hulu total area, $390.000 \mathrm{Ha}$ is an area of water or logged 13,7\% of the total area in West Kalimantan, and the rest 2.594.200 is in the form of terrestrial unlogged area $(21,9 \%)$ of the unlogged area in West Kalimantan.

Kapuas Hulu geographical position is an important position primarily related to water system control in West Kalimantan because it is upstream of Kapuas River that flows through almost all districts in West Kalimantan, (except Ketapang District) and empties into the West Coast of West Kalimantan.

Generally, Kapuas Hulu is a lowland area as well as lake and swamp areas. There are some rivers in Kapuas Hulu which extend to the east of West Kalimantan, such Kapuas River which has several tributaries located in Kapuas Hulu, i.e., Embaloh River, which is the upstream of the North, Mandai River.

Moreover, there are eight other principal tributaries where its role is very influential in meeting the needs of transport accommodation for passengers and goods from district to city and sub-district. The terrain around the watershed border is considered a source zone of agricultural land. Moderately settled agriculture is conducted intensively in the river plains which is narrow, while the ordinary shifting cultivators have influenced many of these watershed plains.

TABLE I. FISH PRODUCTION IN THE WATER BASED ON SUB-DISTRICT IN KAPUAS HULU (TON)

\begin{tabular}{|l|l|l|l|l|l|}
\hline $\begin{array}{l}\text { Sub- } \\
\text { District }\end{array}$ & Jelawat & Toman & Lais & Belida & Total \\
\hline Silat Hilir & 22,70 & - & 85,80 & 17,00 & 387,47 \\
\hline Silat Hulu & - & - & - & - & 203,02 \\
\hline $\begin{array}{l}\text { Hulu } \\
\text { Gurung }\end{array}$ & - & - & - & - & - \\
\hline Bunut Hulu & - & - & - & - & - \\
\hline Mentebah & - & - & - & - & - \\
\hline Bika & 9,00 & 27,60 & 118,00 & 13,00 & 786,71 \\
\hline Kalis & - & - & - & - & - \\
\hline $\begin{array}{l}\text { Putussibau } \\
\text { Selatan }\end{array}$ & 0,50 & - & - & 0,25 & 335,94 \\
\hline $\begin{array}{l}\text { Embaloh } \\
\text { Hilir }\end{array}$ & 28,60 & 2135,00 & 253,00 & 37,90 & 3 \\
\hline Bunut Hilir & 193,00 & 2387,00 & 706,00 & 549,00 & 5 \\
& & & & & 383,83 \\
\hline Boyan & - & - & - & - & - \\
\hline
\end{tabular}




\begin{tabular}{|l|l|l|l|l|l|}
\hline Tanjung & & & & & \\
\hline Pengkadan & - & - & - & - & - \\
\hline Jongkong & 18,70 & 147,10 & 242,80 & 39,60 & 1 \\
& & & & & 138,09 \\
\hline Selimbau & 69,00 & 185,90 & 342,00 & 32,40 & 2 \\
& & & & & 146,84 \\
\hline Suhaid & 47,00 & 179,70 & 331,60 & 87,40 & 2 \\
& & & & & 219,78 \\
\hline Seberuang & - & - & - & - & - \\
\hline Semitau & 17,00 & 122,50 & 57,20 & 19,00 & 977,05 \\
\hline Empanang & - & - & 50,60 & - & 50,60 \\
\hline $\begin{array}{l}\text { Puring } \\
\text { Kencana }\end{array}$ & - & - & - & - & - \\
\hline Badau & 7,80 & 30,20 & 79,70 & 6,60 & 859,77 \\
\hline $\begin{array}{l}\text { Batang } \\
\text { Lupar }\end{array}$ & 8,20 & - & 98,40 & 9,90 & 822,92 \\
\hline Embaloh & - & - & 41,20 & - & 107,70 \\
Hulu & & & & & \\
\hline $\begin{array}{l}\text { Putussibau } \\
\text { Utara }\end{array}$ & 0,50 & - & - & - & 186,54 \\
\hline Year 2015 & 422,00 & 5523,70 & 2 & 812,05 & 18 \\
& 598,10 & 8768,10 & 406,30 & 953,05 & 548,70 \\
2014 & 377,00 & 9129,10 & 2 & 363,50 & 35 \\
& 362,00 & 8998,30 & 562,70 & 350,00 & 013,40 \\
2013 & 469,50 & 855,50 & 2 & 319,00 & 34 \\
& & & 362,70 & & 636,70 \\
2012 & & & 2 & & 29 \\
& & & 120,70 & & 016,50 \\
2011 & & & 1 & & 20 \\
\hline & & & & & \\
& & & 928,64 & & \\
\hline
\end{tabular}

The geographical condition with many streams of rivers and tributaries makes Kapuas Hulu has the potential of much freshwater fish production from its rivers. Geographical condition, as explained above, made Kapuas Hulu is rich in superior potential that can be developed and offered to investors, such as the food processing industry fishery sector.

\subsection{Kerupuk Basah as Kapuas Hulu Typical Potential}

When we heard the term "KerupukBasah," we probably think of it as being wet by water; then the fried KerupukBasah will be wet. Such an assumption is mistaken because Kepuruk Basah as typical food that we can find in Kapuas Hulu has an elongated shape and jelly-ish texture when it is tasted, which tastes more delicious with peanut sauce.

Kerupuk Basah is made from fish. Generally, the people make Kepuruk Basah from Belinda and toman fish that are mostly found in Kapuas Hulu upstream river, because geographically, Kapuas Hulu has many tributaries that have potential as the habitat of Belinda and toman fish. 
Kerupuk Basah is Kapuas Hulu's typical food, and a local community called it "temet." There is no accurate historical record about when the food is famous in Kapuas Hulu society. Today, Kerupuk Basah has become a compulsory food for Kapuas Hulu society.

The process of Kerupuk Basah making is not too complicated. The tricky thing is to find the fish as Kerupuk Basah material because it is only found in Kapuas river upstream. The original raw material of this Kerupuk Basah is Belinda fish. However, this type of ancient fish is increasingly rare, difficult to obtain, and expensive. Its successor is toman fish that is no less delicious, and it still can be found in Kapuas Hulu. For $5 \mathrm{~kg}$ of toman fish meat, clean without bone anymore, milled mix $1 \mathrm{~kg}$ of starch. Seasonings including garlic, pepper, and salt are stirred in flour with a little water until thick enough to be rolled. Then the sponge is inserted in boiling water until it is supple.

At first glance, temet or Kerupuk Basah like empek empek Palembang, but the big difference is in the ingredients of this food that comes from freshwater fish. The most commonly used fish for making KerupukBasah are toman and Belinda fishes. Another difference is the chili is served as a complement to this wet crackers. If empek empek is served with vinegar. Wet crackers are served with peanut sauce as a compliment.

Therefore, Kerupuk Basah processed from freshwater fish, especially Belinda and toman fish that are only found in Kapuas Hulu upstream, West Kalimantan, has geographical indications communally that should be given protection of intellectual property rights.

\subsection{Gegraphical Indication Protection as part of the Intellectual Property Rights}

The understanding of Intellectual Property Rights (IPR) can be interpreted as risen rights from the results of human thought, produces a product or useful process for human. (1) Generally, it can be said that the object set in IPR is risen works or born due to human intellectual ability. IPR is divided into two following parts [5] [4]:

1. Copyrights

2. Industrial property rights, consisting of:
a. Patent;
b. Trademark;
c. Industrial designs;
d. Integrated circuits;
e. Trade secret;
f. Geographical indication; and
g. Plant variety protection.

A geographical indication is part of the IPR. In understanding the relationship between IPR and geographical further, it can be traced by a geographical indication concept. A geographical indication is a sign used on goods that have a specific geographical origin and possess qualities or a reputation of that place of origin. Often, a geographical indication consists of the name of the place of origin of the goods. Agricultural products typically have qualities that derive from their place of production and are influenced by specific local factors, such as climate and soil. Whether a sign functions as a geographical indication or not is a matter of national law and consumer perception [2].

WTO gives the limitation of geographical indication with place names (in some countries also words associated with a place) used to identify the origin and quality, reputation or other characteristics of products (for example, "champagne," "tequila," or "Roquefort"). Moreover, this shows that the WTO, as the maker of international trade law, 
has a vital role in transforming things into a commodity to which intellectual property rights are applied [2].

Based on Article 1 (2) the Paris Convention for the Protection of Industrial Property of 1883, the geographical indication is a part of industrial property. It is stated that Protection of Industrial Property has its object Patents Utility Models, Industrial Designs, Trademarks, Servicemarks, Tradenames, Indication of Source of Appellation of Origin, and the repression of Unfair Competition".

Another definition can be found in Article 2 (1) of the Lisbon Agreement for the Protection of Appellations of Origin, which stated that the geographical name of country, region, or locality, serves to designate a product originating therein the characteristic qualities of which are exclusive or essential to geographical environment, including natural and human factor.

The WTO Agreement on Trade-Related Aspects of Intellectual Property Rights (TRIPs) stipulates the definition of geographical indications as follow [5]: Geographical indications are indications which identify a good as originating in the territory of a country, or a region or locality in that territory, where a given quality, reputation or another characteristic of the good is primarily attributable to its geographical origin.

Recently, geographical indication in Indonesia is regulated by Act 20 of 2016 on Trademark and Geographical Indication. This regulation mentioned that geographical indication is a sign for indicating the origin of an item and/or a product. It is determined by geographical environment factors including a natural factor, a human factor, or a combination of both factors that provides a reputation, quality of certain goods, and characteristics of the produced goods.

There are two geographical indication scope as regulated by Article 1 Government Regulation 55 of 2007 on Geographical Indication.

1. A sign is place name or region or other sure sign which indicates where the goods are produced and protected by a geographical indication.

2. Goods that may include agricultural product, processed product, handicraft, or other items.

Geographically, Kapuas Hulu is territorial water, lakes, and swamps, including Kapuas rivers. This location is perfect for fishes, i.e., jelawat, gabus, betutu, toman, lais, tambakan/sepat siam, Belinda, and others. The fishes, especially toman and Belinda fishes, are processed by the Kapuas Hulu community to create a new processed product called Kerupuk Basah. The combination of both signs and goods compose a product of Kerupuk Basah.

Today, Kerupuk Basah has a good reputation and quality which has been familiar in West Kalimantan as typical food. The human factor is one of the most important in Kerupuk Basah making because it is a handmade food without artificial preservatives.

Kerupuk Basah has similar characteristic with empek empek and siomay, but Kerupuk Basah's shape is elongated round, and it is usually made from Belinda fish which contains much fat. This food is very good for human's health because it contains omega 3, amino acid, vitamin A, B, D, and carbohydrates.

Kapuas Hulu's Kerupuk Basah can be steamed or fried before eating. This food will be completed if it is enjoyed with typical chili sauce in the form of spicy peanut sauce and savory. Through that description, we can conclude that Kerupuk Basah can be registered as a Geographical Indication Kapuas Hulu.

D. Local Government Role in Optimizing Geographical Indication Registration 
A geographical indication is different from other intellectual property aspects, such as patent, trademark, copyrights, and design industry. Geographical indication product is protected after it is registered. As long as the sign is not registered in the Intellectual Property Minister, it is not protected. Here, the role of local government is vital.

The use of law as a tool of social engineering involves the use of rules issued by lawmakers to have consequences for the role done by the society member and by the government. The consequences on the role it generates will affect how society feedback and government as role occupant for the determined legal norms.

The study found that law as a tool of social engineering involved the use of legislation issued by lawmakers to cause consequences for the roles performed by community members and officials. One factor that affects legal protection of wet crackers as a geographical indication of Kapuas Hulu is the role of the local government of Kapuas Hulu Regency in registering wet crackers as a geographical indication of Kapuas Hulu.

Article 53, Act 20 of 2016 on Trademark and Geographical Indication determined that geographical indication is protected after the Minister registers it after the following applicants apply:

1. The community in the geographical area is represented by the institution which attempts the following goods or products:

a. natural resources;

b. handicraft items; or

c. industrial results.

2. Provincial or district/city Local Government

Geographical indication guiding and monitoring is done by the Central Government and Local Government based on their authorities in Article 70 and Article 71 Act 20 of 2016 on Trademark and Geographical Indication. The guiding consists of:

1. Preparation to fulfill georaphical indication application requirements;

2. Geographical indication registration requirement;

3. Benefit and commercialization of geographical indication;

4. Socialization and understanding of geographical indication protection;

5. Geographical indication product mapping and incentivization;

6. The training and guiding;

7. Monitoring, evaluation, and supervision;

8. Legal protection;

9. Facilitation of developing, processing, and marketing the geographical indication of goods and product.

It means that Local Government has the authority to register geographical indication. Related to the works of Act 20 of 2016 on Trademark and Geographical Indication in Kapuas Hulu society, the economic value of Kerupuk Basah as a geographical indication has been affected by three factors, i.e., institution law-making role, institution sanction role implementer, and role occupant. Role occupant is the parties which have been regulated in this law, including Local Government, Kapuas Hulu, Local Government. Act 20 of 2016 on Trademark and Geographical Indication regulate that Kapuas Local Government role is very significant to register, guide, and monitor Kerupuk Basah as Geographical Indication of Kapuas Hulu.

Lawrence M. Friedman stated that there are three parts of the legal system, namely structure, substance, and legal culture. The legal structure is a body-related form, pattern, persistent system of how legislative does its functions as a lawmaking institution. The legal substance is a set of legal rules, norms, social, behavioral patterns, or actual rules or norms 
used by institutions, including existing law. The third, legal culture-related ideas, attitudes, beliefs, expectations, and opinions about the law. [6]

Related with unregistered Kerupuk Basah as Kapuas Hulu's geographical indication, then from the three legal systems, the legal culture is the reason. It has been mentioned earlier that the legal culture is concerned with ideas, attitudes, beliefs, expectations, and opinions about the law.

The mindset that has been formed so far in the ideas, beliefs, expectations, and opinions of the local government of Kapuas Hulu that registering wet crackers as a geographical indication is not necessary to be a determinant of the less concerned attitudes of the local government of Kapuas Hulu in registering Kerupuk Basah as a geographical indication.

Kapuas Hulu Local Government assumes that such registration is not necessary because of the belief that without being registered, anyone else must have been aware of the existence of Kerupuk Basah as typical food from Kapuas Hulu. Also, the lack of care of Local Government Kapuas Hulu in registering Kerupuk Basah as a geographical indication is supported by the perception of Kapuas Hulu Local Government.

The actions of a person (in the pursuit of the meaning) are influenced by his perception or his view toward the object. The actions or deeds of a human being are actions or deeds about or against something, while its perception or view of something influences the "color" of the action itself. Human beings react to their environment not based on stimulation coming from the environment but based on their perception (interpretation of what is couched) on the stimulation. Meanwhile, perception itself is a process of individual consciousness concerned that is strongly influenced by the individual's circumstances themselves, experience, level of intelligence, education, interests, and social background [7].

Based on the research, it can be said that attitudes or human behavior in dealing with something it faces are influenced by its perception of the meaning of something. Unregistered wet crackers as a geographical indication are influenced by the perception of Kapuas Hulu Local Government, the low commitment of role occupant, and the lack of coordination between related institutions as role occupant to realize Kerupuk Basah as a geographical indication that needs the protection of the Directorate General Intellectual Property and Human Rights. Administration coordination and perception equation are urgently required for the common geographical indication in order to improve economic value for social welfare.

\section{Conclusion}

Kerupuk Basah has a high economic potential value, so it is urgent to register a common geographical indication. However, the mechanism of the geographical indication registration is not optimal yet, because there is no specific role occupant. We recommend that it needs a local policy to determine a particular institution which must register geographical indication.

\section{References}

[1] B.; M. A. and T. J.-M. G, "Geographical Indications, Public Goods, and Sustainable Development: The Roles of Actors,', Strateg. Public Policies World Dev., vol. 98, pp. 45-57, 2017. 
[2] O. C. [et al. . Deselnicu, "A Meta-Analysis of Geographical Indication Food Valuation Studies: What Drives the Premiums for origin-based Labels?," J. Agric. Resour. Econ., no. 19, p. 204, 2012.

[3] J. D. Z, "Using Intellectual Property Rights to Create Value in the Coffee Industry Marquette," Intellect. Prop. Law Rev., vol. 16, p. 283, 2012.

[4] D. Samsudin, "HAK KEKAYAAN INTELEKTUAL DAN MANFAATNYA BAGI,” 2016.

[5] A. and G. A. F, "Geographical Indications beyond Wines and Spirits: A Roadmap for a Better Protection for Geographical Indications in the WTO/TRIPS Agreement," J. World Intellect. Prop., vol. 5, no. 6, pp. 865-897, 2002.

[6] L. Friedmann, The Legal System. New York: Russel Sage Foundation.

[7] M. G. M. and P. D. L, "Geographical Indications and the Competitive Provision of Quality in Agricultural Markets American," J. Agric. Econ., vol. 90, no. 3, pp. 794$812,2008$. 